\title{
Association of Clinical Pathologists: 78th General Meeting
}

The 78th general meeting of the Association of Clinical Pathologists was held in Shrewsbury on 30-31 March and 1 April. The meeting included two symposia, one on 'Dialysis for chronic renal failure' and the second on 'Immuno-diffusion techniques in the routine hospital laboratory'. The speakers on both topics were invited. Professor B. Levi Della Vida had been invited to give a special lecture which he did on 'A foreigner's view on clinical pathology'. Abstracts of some of the other papers follow.

UNSUSPECTED ANAEMIAS: THE CASE FOR POPULATION SCREENING

E. G. REES (Shrewsbury) with R. M. A. MOORE and PATRICIA WYCHERLEY The age distribution in Dr. Moore's practice was proved representative of that of the general population and a one in four random sample, totalling 800 , was approached. Those aged over 70 were visited, the remainder asked to attend the laboratory for $\mathrm{Hb}$ estimation. The total response was $584(73 \%)$ of whom 419 were normal; 85 had 'trivial' anaemia $(\mathrm{Hb}=11.0 \mathrm{~g}-$ $11.6 \mathrm{~g}$ females, or $12.0 \mathrm{~g} .-12.6 \mathrm{~g}$. males); and 80 had 'significant' anaemia $(<11.0 \mathrm{~g}$. females, $<12.0 \mathrm{~g}$. males). This last group was composed mainly of those aged under 15 and over 70, and females between 15 and 45 . The majority had no symptoms related to anaemia, nor was it suspected.

Iron deficiency occurred mainly in young females. Dietary deficiency was maximal in those under 9 years, some being regarded as 'relative' deficiencies as these children were either very tall or large for their age. Secondary anaemias (13) occurred mainly in young boys with chronic urinary tract infection. A group (20), mainly children, were unclassified, some responding to iron therapy (without laboratory proof of iron deficiency). Other anaemias resulted from blood loss (17), folate deficiency (5), and vitamin $\mathbf{B}_{12}$ deficiency (1). Some had more than one cause for the anaemia.

The incidence of anaemia in the population has been shown to be much higher than is suspected and therefore screening (automated) procedure should be adopted. Although our anaemic patients were thought to be symptomless, many responded to specific therapy and this is evidence in favour of 'presymptomatic' diagnosis.

\section{POST-INFECTIVE ISCHAEMIA OF THE BONE MARROW} IN MEGALOBLASTIC ANAEMIA

H. B. GOODALl (Royal Infirmary, Dundee) Necrosis of the bone marrow, though uncommon, may be seen occasionally in cases of caisson disease, sickle cell disease, pancreatic disease, carditis (rheumatic and bacterial), peripheral vascular disease, symmetrical peripheral gangrene, leukaemia, corticosteroid therapy, and alcoholism. This paper (with demonstration) reported two cases of megaloblastic anaemia complicated by necrosis of the bone marrow.

The first was of a man aged 41 with malabsorption syndrome associated with old tabes mesenterica. Calculous hydronephrosis and chronic pyelonephritis were also present. During relapses this man had megaloblastic anaemia with low serum folate levels. $\mathrm{He}$ had been treated with prednisolone because acquired haemolytic anaemia had been suspected and he developed acute staphylococcal bronchopneumonia. Despite antibiotics, folic acid, and cyanocobalamin, he died. Post-mortem examination showed, as well as the above lesions, necrosis of sternal marrow and a unique ischaemic lesion of the femora featured by megakaryocytolysis with a striking investment of these damaged giant cells with fibrin which in places involved the sinusoids.

The second patient was a woman aged 38 with megaloblastic anaemia of pregnancy, $E$. coli infection of the urinary tract, and massive cryofibrinogenaemia who on exposure to cold collapsed and consequently sustained aseptic, avascular necrosis of the head of the right femur which later required arthroplasty.

The pathogenesis of these lesions was discussed.

\section{FURTHER EXPERIENCE WITH A RADIOISOTOPE DILUTION METHOD FOR MEASURING VITAMIN $B_{12}$ IN SERUM}

J. L. RAVEN, P. L. WALKER, and P. BARKHAN (Guy's Hospital, London) A radioisotope dilution method for measuring the concentration of vitamin $B_{12}$ in human serum has now been in use for the past 15 months and the present communication is an extension of previously published observations (Raven, Walker, and Barkhan, 1966). Over 400 sera have been assayed in parallel with a microbiological method ( $L$. leishmannii) and further experience confirms the validity and accuracy of the radioisotope method.

While it would simplify the assay to use a common serum supernatant control this has been found to reduce the accuracy of the results and a separate supernatant 
control for each serum appears to be more satisfactory. The stability of our intrinsic factor preparation when used in the intrinsic factor control tubes is enhanced by the presence of serum, and for this purpose a 1:10 dilution of a vitamin $B_{12}$-deficient serum is used. The addition of cyanide to the assay system gives significantly higher values only when the serum $B_{12}$ concentration is above $500 \mathrm{pg} . / \mathrm{ml}$; ; below this value cyanide produces no incremental effect. Different hog intrinsic factor preparations (Lederle and Armour) have been used and when accurately standardized gave satisfactory results. Our charcoal preparation is not effective when coated with haemoglobin and bovine albumin is still used. The radioisotope assay, unlike the microbiological assay, was not affected by the presence of antibiotics in the serum.

With the present method a batch of 30 sera can be assayed by a single technician in four hours but an automatic counter would reduce the time considerably.

\section{REFERENCE}

Raven, J. L., Walker, P. L., and Barkhan, P. (1966). J. clin Path., 19,610 .

\section{SERUM PEPSINOGEN AS AN INDEX OF GASTRIC INTRINSIC FACTOR SECRETION}

N. K. SHINTON, M. Y. EARLY, and S. PADMANABHA (Coventry) The levels of serum pepsinogen, estimated by the method of Edwards, Jepson, and Wood (1960), were compared with those of intrinsic factor secretion determined by the rapid charcoal dialysis method of Gottlieb, Lau, Wasserman, and Herbert (1965). Intrinsic factor assays were carried out on the total gastric juice aspirated for one hour before and one hour after maximal stimulation by 3-beta-aminoethyl pyrazole dihydrochloride (Histalog) in doses of $1.5 \mathrm{mg} . / \mathrm{kg}$. body weight. The blood for serum pepsinogen estimation was collected during the post-stimulation hour. These determinations were made on specimens from five normal volunteers and 21 hospital patients, 10 of whom had been diagnosed as having pernicious anaemia. A poor correlation was found when the pepsinogen level was compared with either the intrinsic factor concentration or the total intrinsic factor secretion during the pre-stimulation hour but a significant correlation was found with the total intrinsic factor secretion during the post-stimulation hour. While the patients with a pepsinogen level below 100 units $/ \mathrm{ml}$. had a total intrinsic factor secretion during this hour of less than 700 units, two of the normal volunteers with pepsinogen levels of 55 and $61 \mathrm{units} / \mathrm{ml}$. had total intrinsic factor secretion of 2,465 and 3,337 units. One patient with irondeficiency anaemia had a normal pepsinogen level of $186 \mathrm{units} / \mathrm{ml}$. but a low intrinsic factor secretion of 459 units. It is concluded that while a serum pepsinogen level of less than 100 units $/ \mathrm{ml}$. is not an absolute indication of intrinsic factor deficiency it can be used as a diagnostic screening procedure of particular value in the differential diagnosis of vitamin $\mathbf{B}_{12}$ deficiency.

\section{REFERENCES}

Edwards, K., Jepson, R. P., and Wood, K. F. (1960). Brit. med. J., $1,30$.

Gottlieb, C., Lau, K. S., Wasserman. L. R., and Herbert, V. (1965), Blood , 25, 875 .

\section{DIAGNOSIS BY LYMPH NODE ASPIRATION}

J. J. TAYLOR (Birmingham) Aspiration biopsy, commonly employed in other fields, has been extended to lymphadenopathy; the results confirm the diagnostic value and reliability of this procedure reported by others.

Particular advantages are simplicity, safety, convenience, and ease of repetition. There is no evidence that tumour spread is enhanced by aspiration biopsy. Possible disadvantages are the small size of the specimen, structural damage by the needle, and local haemorrhage. Subsequent full biopsy is not precluded, and in the numerous cases where this has been carried out no distortion of the histological picture has been seen.

The technique and typical appearance were illustrated and an analysis of 262 consecutive lymph node aspirations was presented. The method is in daily use and is of particular value in the out-patient clinic and the follow-up department.

\section{A SIMPLE METHOD FOR DETECTING ASBESTOS IN TISSUE}

c. GOLD (Department of Pathology, Victoria Infirmary of Glasgow) The present methods of detecting asbestos using sputum smears, lung scrapings, ordinary $6 \mu$ sections, thick sections of 30 and $100 \mu$, and microincineration are all useful but have certain disadvantages. This is particularly so when asbestos is scanty, 'hidden' by other dust, or present mainly in the form of naked fibres.

In collaboration with A. W. Kerr, a quick and simple 'one-tube' method has been evolved which yields a stained concentrated dust extract suitable for permanent mounting. The method can be used for fresh or fixed lung, pleural or tumour tissue, lymph nodes, biopsy trimmings, or even deparaffinized blocks of tissue already sectioned and examined. No special apparatus is required.

Diced tissue is digested by $\mathbf{4 0} \% \mathrm{KOH}$ in a universal container or a 4in. $\times 1$ in. round-bottomed centrifuge tube. Digestion is facilitated by boiling for 15 minutes or incubating at $60^{\circ} \mathrm{C}$. for two to three hours. The centrifuged washed deposit is treated with Perls's reagent in the same tube; recovered, dried, and mounted as a smear preparation.

A single block of lung tissue measuring about $15 \times 10$ $\times 6 \mathrm{~mm}$. will yield three smears representing the equivalent of 1,000 serial $6 \mu$ sections, $20030 \mu$ sections, or 60 of $100 \mu$.

The method readily demonstrates stained and unstained asbestos bodies, naked fibres, 'hidden' and atypical forms of asbestos entrapped in the concentrated dust extract.

The dust acts as a carrier for asbestos allowing visual control at all stages, simplifying the microscopical search by acting as a tracer.

Micro-incineration can subsequently be carried out on the smears if desired.

CLINICAL ASPECTS OF CHRONIC DIALYSIS

A. C. KENNEDY (Glasgow) It is important to utilize 
fully the basic regimen for conservative management of chronic renal failure in all patients before it is decided that haemodialysis is essential. Attention to possible infection and/or obstruction, to electrolyte balance, blood pressure control, and protein intake often produce worthwhile benefit which may be maintained for many months. The Giovanetti diet has been a useful advance in dietary management. Factors covering selection of patients for chronic dialysis are age, absence of associated disease such as lupus erythematosus or diabetes mellitus, absence of serious cardiac or cerebral disease, intelligence and motivation of the patient, accessibility to dialysis facilities. An additional factor to be considered is absence of recent hepatitis. When the patient is established on a programme a moderate protein intake is permissible but there must be strict control of fluid and salt. Shunts remain the aspect of the procedure which gives most trouble and clotting episodes and infection represent significant problems in management. The development of subcutaneous arteriovenous fistulae may represent a major advance. Complications from dialysis include technical problems, errors in dialysate composition, calcification of soft tissues, pseudo-gout, haemosiderosis, and hepatitis. Polyneuropathy and pruritis should respond to more vigorous dialysis. Control of hypertension can usually be achieved provided the patient cooperates in respect of fluid and salt intake and if dialysis is efficient. Blood transfusion requirements are probably much less than was originally thought provided one allows the patients to stabilize out at a relatively low P.C.V.

Approximately 120 patients are at present being treated by chronic dialysis in Britain and facilities are actively being planned to bring the total to about 600 patients. It is probable that the number of patients suitable for treatment is of the order of 2,000. More extensive use of home dialysis is undoubtedly worth exploring but not all patients will be suitable.

\section{BIOCHEMICAL ASPECTS OF DIALYSIS FOR CHRONIC RENAL FAILURE}

M. R. WILls (Department of Chemical Pathology, Royal Free Hospital, London) The biochemical consequences of chronic renal disease are the end results of a failure of the kidneys to act as the ultimate guardians of the constitution of the internal environment. The kidneys carry out their homeostatic functions by the processes of glomerular filtration, tubular reabsorption and secretion; regulating the concentration of metabolic wastes, the osmotic pressure, the volume and ionic composition of the internal environment. In the Renal Unit of the Royal Free Hospital patients are treated with twiceweekly haemodialysis in periods of from 14 to 16 hours, using a single pass, warm, two-layer Kill dialyser with negative pressure. The results are presented of routine biochemical estimations on 26 patients when first admitted to the dialysis programme and on current predialysis specimens while on the programme. The initial pre-dialysis results reflect the biochemical changes in relatively uncontrolled chronic renal failure and the current pre-dialysis values reflect the control achieved on chronic haemodialysis treatment. Post-dialysis blood levels are also presented which reflect the efficiency of the dialysis system.

In chronic renal failure intermediary metabolic products of protein catabolism accumulate and it seems probable that some of these substances diffuse into the brain and other tissues, and the toxaemia of chronic renal failure is due to a summation effect of these organic compounds, possibly including urea, acting as enzyme inhibitors. Intermediary metabolism also gives rise to a number of acids and the inability of the diseased kidney to excrete the protons released from these acids accounts for the acidosis of chronic renal failure which also affects cellular metabolism. The alterations in cellular metabolism consequent upon the retention of 'organic compounds' and 'acidosis' are discussed, together with their effects on electrolyte, bone, lipid, protein, and carbohydrate metabolism.

\section{ANTIBIOTIC SUPPRESSION OF PREGNANCY BACTERIURIA: BACTERIOLOGICAL ASPECTS}

L. GANGUl and J. D. SLeigh (Dumbartonshire) Significant bacteriuria was detected in 595 of 9,741 pregnant women $(6.1 \%)$ and in 118 of 1,443 married but infertile women $(8.2 \%)$ attending clinics at Edinburgh Royal Infirmary. One hundred and twenty-seven of the pregnant women who were asymptomatic received a 14-day course of chemotherapy to suppress bacteriuria; 62 were given sulphadimidine, 65 cycloserine. Both drugs were equally effective and at the conclusion of treatment 96 of the 127 women $(75 \%)$ were free from bacteriuria. Follow-up specimens of urine were examined during the remainder of pregnancy and it was found that bacteriuria recurred in 31 patients; 65 of the 127 women, however, remained free from bacteriuria. Successful treatment prevented syptomatic urinary infection during pregnancy and in the immediate post-partum period.

\section{DIFFERENTIATED HUMAN LIVER CELLS IN CULTURE}

A. J. ZUCKERMAN (London) To talk about liver cells in tissue culture is to consider a complex of many different cell types. There have been numerous and extensive efforts to cultivate differentiated liver cells in vitro and equally many attempts to establish liver cell lines. These efforts have met with considerable difficulties and many failures.

Some success was obtained by Hillis and Bang (1962) using a collagen substrate and small primary explants of human embryonic liver in roller tubes. The best growth medium consisted of $20 \%$ inactivated horse serum, $10 \%$ of a $50 \%$ chick embryo juice extract, and $70 \%$ Hank's solution. There was no multiplication of parenchymal cells beyond three weeks, although metabolic activity continued apparently for up to 100 days after explantation. Growth of the parenchymal cells was accompanied by sheets of squamous-like epithelium, fibroblasts, and macrophages.

Chang (1954) reported continuous cultivation of epithelial-like cells from human liver grown in $20 \%$ human serum and $5 \%$ chick-embryo extract. The cells are transferred by trypsinization. It is not suggested, and it is not claimed, that these cells represent differentiated parenchymal liver cells. In fact to refer to this line, 
as is commonly the practice, as human liver cell line, is a misnomer-particularly since Chang cells developed the characteristics of neoplastic tissue.

We modified a method of direct implantation of fragments of liver to form a monolayer of cells. This technique gives rapid separation of cells without destruction of the normal architecture of the tissue and without loss of viability. The cells recover from the traumatic effects of the procedure within a few hours, and the monolayers so obtained can then be used. It is, therefore, not necessary to await the growth and multiplication of the complex of hepatic cells which involves the chance of changes in morphology, differentiation, and transformation of the cells.

Two critical factors are involved in this technique. The first problem was that of disaggregation of the tissue. Mechanical disaggregation proved unsuitable. The preparation of cell suspensions with the proteolytic enzyme Pronase, a protease prepared from Streptomyces griseus, resulted in aggregation of the cells into large clumps after washing. The use of trypsin resulted in good cell dispersion. It is essential, however, to trypsinise the cells gently at room temperature.

The second critical factor is the growth medium. Of many growth media investigated, survival of liver cells was found to be most consistent in a growth medium containing Eagle's minimum essential medium and $10 \%$ foetal calf serum.

It is estimated that over $90 \%$ of the hepatic cells survive for up to 23 days. Subcultivation is not possible.

Autoradiographic studies have shown that the liver cells will incorporate tritiated orotic acid, uridine, and thymidine, indicating that the hepatic cells synthesize both R.N.A. and D.N.A.

After some days in culture many hepatic cells acquire cytoplasmic granules, shown to consist of neutral fat, and these can be metabolized by the addition of insulin to the growth medium. Glycogen is present in the hepatic cells as shown by staining with Best's carmine and the P.A.S. technique for glycoproteins. These cell cultures have been used to localize the action of aflatoxin $B_{1}$ on the human liver cell to messenger-R.N.A., for the investigation of viral hepatitis, for electron-microscope studies, and for E.M. autoradiography. Other studies on protein synthesis, the cytopathology of a number of viruses, and the mode of action of various drugs on the liver cells are also in progress.

We have now also modified our technique for the culture of needle biopsies of adult liver. Approximately half the specimen is retained for routine histological examination, and the remaining tissue is placed in medium 199 and transported to the laboratory immediately on melting ice. The tissue is cut with scalpels into small pieces and placed stationary in $0.2 \%$ trypsin for 30 minutes at room temperature. The cells are subsequently cultured by the method described above.

\section{REFERENCES}

Chang, R. S. (1954). Proc. Soc. exp. Biol. (N.Y.), 87, 440. Hills, W. D., and Bang, F. (1962). Exp. Cell Res., 26, 9.

DATA PROCESSING IN A CLINICAL LABORATORY

M. K. AleXANDER and A. P. PRIOR (Warwick Group
Laboratory) The ever-increasing flood of laboratory data presents both a challenge and an opportunity.

The challenge is to provide reports when and where required; the opportunity arises from the fact that methods and equipment suitable for this task may be so designed that data can also readily be manipulated statistically to assist in problems of quality control, laboratory management, and clinical research.

A system of processing biochemical, haematological, and serological data based on punch cards has been developed. The punch card is prepared from the request form and used in the preparation of laboratory work sheets. When the work is finished, the card is completed by the addition of the results and used to operate an automatic typewriter to produce a report. Urgent reports are sent to outlying hospitals by a facsimile transmission system.

The punch cards can then be sorted on a card sorter or be available as computer input.

The system has shown itself suitable for the production of cumulative reports on selected patients, for the measurement of laboratory work loads, and for control of the quality of analyses.

\section{CASE STUDIES OF ISCHAEMIC COLITIS}

P. R. GARROD, A. MARSTON, and M. LEA-THOMAS(St. Thomas's Hospital, London) Ischaemia is now recognized as being the underlying cause in some cases of colitis, especially in older age groups. Disease affecting the cardiovascular system is a common predisposing factor. The distal part of the colon, particularly the splenic flexure, is usually affected. The rectum is never involved. Three patterns of response are seen depending on the severity of the ischaemia and the virulence of the bowel bacteria. In the most severely affected gangrene of the bowel will result. An intermediate state in which complete necrosis is avoided commonly results in fibrous stricture formation. In the least severely affected complete healing of the damaged tissue occurs. Abdominal pain of sudden onset followed by rectal bleeding are the commonest clinical features. The pathological appearances of the intermediate and least severe forms resemble a healing infarct, the submucosa and muscle coat showing inflammatory granulation tissue and collagenous scar tissue. Large numbers of haemosiderin-filled macrophages are frequently seen.

There are clinical, radiological, and pathological features allowing ischaemic colitis to be distinguished from both ulcerative colitis and Crohn's disease.

INCIDENCE AND SIGNIFICANCE OF ARGENTAFFIN AND PANETH CELLS IN SOME TUMOURS OF THE LARGE INTESTINE

N. M. GIBBS (Guildford) A series of tumours of the large intestine was examined in order to assess the incidence and significance of argentaffin and Paneth cells.

Argentaffin cells were found in adenomatous polyps (41\%), villous adenomas (39\%), polyposis coli $(35 \%)$, Peutz-Jehgers' polyps (100\%), juvenile polyposis $(100 \%)$, and occasionally in adenocarcinomas. 
Paneth cells were found in adenomatous polyps (19\%), villous adenomas $(35 \%)$, polyposis coli $(35 \%)$, PeutzJehgers' polyps (33\%), juvenile polyposis $(100 \%)$, and occasionally in adenocarcinomas. No Paneth cells were found in metaplastic or juvenile polyps.

In some adenomatous polyps, villous adenomas, and one adenocarcinoma occasional argentaffin and/or Paneth cells were present only in the gland crypts and they were surrounded by neoplastic cells. It is concluded that these argentaffin and Paneth cells represent normal crypt cells surviving after the other basiglandular cells have been displaced by neoplastic cells. This process is called 'sequestration'.

However, in some adenomatous polyps, villous adenomas, and adenocarcinomas, argentaffin and Paneth cells appear to be produced by a process of neoplasia and in this event the cells may be abnormal in size and situation in relation to the neighbouring cells, and are scattered throughout the tumour, sometimes in great numbers.

It was found that the crypt unit was retained in PeutzJehgers' polyps, metaplastic polyps, juvenile polyps and juvenile polyposis, and that argentaffin and/or Paneth cells were represented in the basiglandular cells.

It is concluded that a study of the crypt anatomy and cytology provides an aid to the histological interpretation and classification of tumours of the large intestine.

In general the findings support the accepted pathological classification of the tumours investigated.

\section{Reports and Bulletins prepared by the Association of Clinical Biochemists}

The following reports and bulletins are published by the Association of Clinical Biochemists. They may be obtained from Mr. J. T. Ireland, Biochemistry Laboratory, Alder Hey Children's Hospital, Liverpool, 12. The prices include postage, but airmail will be charged extra.

\section{SCIENTIFIC REPORTS}

1 Colorimeters with Flow Through Cells. A Critical Assessment of 4 Instruments. 1965. P. M. G. BROUGHTON and C. RILEY. 13s. 6d.

2 Colorimeters: A critical assessment of 5 commercial instruments. 1966. P. M. G. BROUGHTON, C. RILEY, J. G. H. COOK, P. G. SANDERS, and H. BRAUNSBERG. 15s.

\section{TECHNICAL BULLETINS}

3 Non-recording Spectrophotometers for the Visible and Ultraviolet Ranges. A comparative table of instruments available in Great Britain. May 1965. A. H. GOWENLOCK, P. C. NICHOLAS, and J. H. WILKINSON. 1s. 6d.

4 Control Solutions for Clinical Biochemistry. June 1965. P. M. G. BROUGHTON and A. H. GOWENLOCK. 1s. 6d.
5 Recording Spectrophotometers. A comparative list of low-priced instruments readily available in Britain. July 1965. P. SEWELL. 2s. 6d.

6 A Guide to Automatic Pipettes. A list of more than 100 instruments compiled from manufacturers' literature. August 1965. P. M. G. BROUGHTON. 5s.

7 Variability Between AutoAnalyzer Modules. August 1965. B. E. NORTHAM. 1s. 6d.

8 Flame Photometers. A comparative list of 15 instruments readily available in Britain. June 1966. C. RILEY. 4s.

9 Determination of Urea by AutoAnalyzer. November 1966. RUTH M. HASLAM. 2s. 6d.

10 Filter Fluorimeters. A comparative list of 14 instruments. March 1967. HANNELORE BRAUNSBERG. $5 s$. 